\title{
ABCG2 and NCF4 polymorphisms are associated with clinical outcomes in diffuse large B-cell lymphoma patients treated with R-CHOP
}

\author{
Duo Liu ${ }^{1,2}$, Nan Wu ${ }^{1}$, Haiming Sun ${ }^{1}$, Mei Dong ${ }^{2}$, Tianzhu Guo ${ }^{3}$, Peng Chi ${ }^{4}$, Guofu $\mathrm{Li}^{5}$, \\ Donglin Sun ${ }^{1}$ and Yan Jin ${ }^{1}$ \\ ${ }^{1}$ Department of Medical Genetics, Harbin Medical University, Harbin, Heilongjiang, China \\ ${ }^{2}$ Department of Pharmacy, Harbin Medical University Cancer Hospital, Harbin, Heilongjiang, China \\ ${ }^{3}$ Department of Pharmacology, School of Basic Medical Sciences, Heilongjiang University of Chinese Medicine, Harbin, \\ Heilongjiang, China \\ ${ }^{4}$ Department of Pharmacy, Harbin Medical University-Daqing, Daqing, Heilongjiang, China \\ ${ }^{5}$ Department of Neurosurvery, Harbin Medical University Cancer Hospital, Harbin, Heilongjiang, China \\ Correspondence to: Yan Jin, email: jinyan@ems.hrbmu.edu.cn \\ Donglin Sun, email: sundl@ems.hrbmu.edu.cn \\ Keywords: diffuse large B-cell lymphoma, rituximab, pharmacogenetic, prognosis \\ Received: October 19, $2016 \quad$ Accepted: March 09, $2017 \quad$ Published: April 06, 2017 \\ Copyright: Liv et al. This is an open-access article distributed under the terms of the Creative Commons Attribution License 3.0 (CC \\ BY 3.0), which permits unrestricted use, distribution, and reproduction in any medium, provided the original author and source are \\ credited.
}

\section{ABSTRACT}

The impact of pharmacogenetics on predicting survival in diffuse large B-cell lymphoma (DLBCL) remains unclear. We tested 337 DLBCL patients treated with rituximab-cyclophosphamide, doxorubicin, vincristine, and prednisone (R-CHOP) for 9 single nucleotide polymorphisms from 6 genes (CD20, FCGR2A, NAD(P)H, ABCC2, $A B C G 2$ and CYP3A5). Patients who carried the NCF4 rs1883112 GG genotype showed significantly shorter progression-free survival (PFS) $(P=0.023)$ and event-free survival (EFS) $(P<0.001)$ comparing with A allele. A significantly shortened PFS $(P=0.013)$ and EFS $(P=0.002)$ was also observed in the patients with $A B C G 2$ rs2231137 GG genotype. Furthermore, the elder ( $>60$ years old) or male patients with ABCG2 rs2231137 GG genotype had poorer PFS and EFS than A allele. Moreover, CD20 rs2070770 CC and RAC2 rs13058338 AT genotypes were independent predictors of chemotherapy-induced toxicity. Cox proportional hazards analyses demonstrated that the GG genotype of ABCG2 rs2231137 and NCF4 rs1883112 were risk factors in DLBCL patients. In conclusion, the identified polymorphisms provide guide for the identification of DLBCL patients who are likely to benefit from chemotherapy.

\section{INTRODUCTION}

Diffuse large B-cell lymphoma (DLBCL) is the most common lymphoid neoplasm, with a wide range of outcomes predicted by the International Prognostic Index (IPI) [1, 2]. Although the introduction of rituximab $(\mathrm{R})$ to the chemotherapy combination of CHOP (cyclophosphamide, doxorubicin, vincristine, and prednisone) has improved prognosis and allowed some tailoring of therapy, a significant fraction of DLBCL patients still fail treatment and die [3-6].
Antibody-dependent cellular cytotoxicity, mediated by effector cells that engage CD20 and the Fc portions of the antibody via receptors (Fc $\gamma \mathrm{Rs}$ ) of immunoglobulin, is thought to contribute most to the efficacy of the antibody against malignant cells of B-cell lymphomas [7, 8]. The T allele of CD20 rs2070770 was significantly associated with superior progression-free survival (PFS) [9], while Ding et al. found no significant association [10]. For FCGR2A, gene-gene interactions analysis revealed rs 1801274 and ILIRN rs419598 combination significantly related to adjusted OS of DLBCL in Denmark [11]. And a significant 
increased NHL risk was observed for the rs1801274 in US [12]. However, no statistically significant difference in survival was found according to rs1801274 allele in Korea [13]. Reactive oxygen species (ROS) involved in cellular functions mediate the therapeutic effects of anticancer drugs. $\mathrm{NAD}(\mathrm{P}) \mathrm{H}$ oxidase is an important endogenous source of ROS, and the small GTPase RAC2 is required for the $\mathrm{NAD}(\mathrm{P}) \mathrm{H}$ oxidase activity [14]. Kim IS et al. observed $A B C G 2$ rs2231142 polymorphism may correlate with chemotherapy-induced diarrhea in Korean patients [15]. Other host's single nucleotide polymorphisms (SNPs) affecting genes involved in drug metabolism, detoxification and transport may contribute to the prognostic stratification and the predicted toxicity in DLBCL patients [16-23]. However, the impact of genetic polymorphisms on drug activity/metabolism and subsequently treatment outcome in DLBCL patients is largely unclear.

Therefore, in this study we assessed the effects of the nine SNPs in the CD20, FCGR2A, NAD $(P) H, A B C C 2$, $A B C G 2$ and $C Y P 3 A 5$ gene on survival in a cohort of 189 Chinese DLBCL patients treated with R-CHOP to define specific subgroups more likely to benefit from therapy.

\section{RESULTS}

\section{Subjects' characteristics}

A total of 189 patients who received R-CHOP as a frontline therapy for DLBCL were included in the current study. All of them were Chinese Han, including 102 males and 87 females with median age at diagnosis of 55.9 years (range 13-84). Clinical characteristics and treatment outcomes of the cohort at DLBCL diagnosis are displayed in Table 1. The CR and ORR were 149/189 (78.84\%) and $152 / 189(80.42 \%)$, respectively.

\section{The correlation of clinical characteristics with variant genotypes}

We detected the association between the variant genotypes and the clinicopathological data of DLBCL according to ECOG ( $\mathrm{PS}=0$ vs. $>1$ ), B symptom, Bulky, Extranodal sites (0 vs. $>1$ ), LDH level (positive vs. negative), Bone marrow involvement, IPI scores (0 to 5), Ann Arbor stage (I, II vs. III, IV), and Subtype (non-GCB vs. GCB). However, the various SNPs were not correlated with clinical characteristics.

\section{Response to therapy and outcome}

Patients who carried the rs1883112 GG genotype showed significantly shorter PFS comparing with A allele (log-rank test, $P=0.023$; Figure $1 \mathrm{~A})$. The estimated median PFS for patients who had the GG, and AA plus AG genotypes of rs1883112 was 29.2 months (95\% CI $=19.7-38.7)$ and 79.1 (95\% CI $=64.4-93.8)$, respectively. Meanwhile, patients with rs1883112 GG genotype had shorter EFS than patients with AA plus AG genotypes (log-rank test, $P<0.001$ ) (Figure 1B).

For $A B C G 2$ variants, we observed a difference in the survival curve for patients. The median PFS was 68.9 months (95\% CI $=46.6-91.1)$ for patients with GG genotype of rs 2231137 , and was 84.5 months (95\% $\mathrm{CI}=66.3-102.7)$ months in the AA plus AG genotypes (log-rank; $P=0.013$; Figure 2A). Moreover, patients with rs2231137 GG genotype also had shorter EFS than patients with AA plus AG genotypes (log-rank test, $P=$ 0.002) (Figure 2B). Furthermore, potential age/gender implications were investigated. We found that elder patients ( $>60$ years old) with GG genotype of rs2231137 displayed a poor PFS (log-rank test, $P=0.004$; Figure $3 \mathrm{~A}$ ) and EFS (log-rank test, $P=0.003$; Figure $3 \mathrm{C}$ ). Meanwhile, male patients with rs2231137 GG genotype had shorter PFS (log-rank test, $P=0.016$; Figure 4A) and EFS comparing with A allele (log-rank test, $P=0.009$; Figure 4C).

With respect to the occurrence of side effects, chemotherapy-induced grade 3 or 4 anemia was less frequent in rs2070770 CC genotype compared with rs2070770 TT $(P=0.024 ; \mathrm{OR}=0.201$, 95\%CI: 0.050 0.807). In addition, we found that rs13058338 AT $(P=0.034 ; \mathrm{OR}=2.659,95 \% \mathrm{CI}: 1.074-6.582)$ was an independent predictor of grade 3-4 hematologic toxicity (Table 2).

\section{Multivariate analysis}

To estimate the independent impact of each variable on PFS and EFS, a descriptive Cox proportional hazard model was established. The results of the multivariate analysis adjusting for IPI are shown in Table 3. Multivariate Cox regression analysis showed that compared to rs 1883112 AA plus AG, the relative risk of GG was 2.410 for PFS $(P=0.030$; $\mathrm{HR}=2.410,95 \% \mathrm{CI}: 1.088-5.338)$, and was 4.464 for EFS $(P=0.001$; HR=4.464, 95\% CI: 2.339 $8.520)$. In addition, the genotype $\mathrm{GG}$ of rs 2231137 was risk factor for EFS in DLBCL patients $(P=0.007$; HR=2.315, 95\% CI: 1.252-4.281).

\section{DISCUSSION}

In this study, we document that: (1) Significantly shortened PFS and EFS after R-CHOP chemotherapy was observed in the patients with $\mathrm{NAD}(\mathrm{P}) \mathrm{H}$ oxidase subunits (NCF4 rs1883112) GG genotype; (2) ATP-binding cassette transporters ( $A B C G 2$ rs231137) may predict PFS and EFS; (3) Elder ( $>60$ years old) or male patients with GG genotype of rs2231137 displayed poor PFS and EFS comparing with A allele; (4) NADPH RAC2 rs13058338 (AT) and $C D 20$ rs2070770 (CC) were independent predictors of chemotherapy-induced toxicity of DLBCL patients.

Rituximab bound to CD20 antigen can be recognized by Fc $\gamma$ receptor on NK cells and macrophages to mediate killing or phagocytosis of the tumor cells [7]. Studies of neutrophils have shown that NCF4 encodes the 
Table 1: Clinical characteristics of the DLBCL cohort at diagnosis

\begin{tabular}{|c|c|}
\hline Clinical characteristics & R-CHOP $(n=189)$ \\
\hline Age (years) & $55.9(13-84)$ \\
\hline Age $>60$ years & $79 / 189(41.80 \%)$ \\
\hline Male: female & $102: 87$ \\
\hline ECOG PS $>1$ & 20/189 (10.58\%) \\
\hline B symptom & 40/189 (21.16\%) \\
\hline Bulky & $58 / 189(30.69 \%)$ \\
\hline Extranodal sites $>1$ & $36 / 189(19.05 \%)$ \\
\hline LDH positive & $44 / 189(23.28 \%)$ \\
\hline Bone marrow involvement & $13 / 189(6.88 \%)$ \\
\hline \multicolumn{2}{|l|}{ IPI } \\
\hline 0 & $67 / 189(35.45 \%)$ \\
\hline 1 & 65/189 (34.39\%) \\
\hline 2 & 25/189 (13.44\%) \\
\hline 3 & $27 / 189(14.29 \%)$ \\
\hline 4,5 & $5 / 189(2.65 \%)$ \\
\hline \multicolumn{2}{|l|}{ Ann Arbor stage } \\
\hline I-II & 89/189 (47.09\%) \\
\hline III-IV & $100 / 189(52.91 \%)$ \\
\hline \multicolumn{2}{|l|}{ Subtype } \\
\hline GCB & $62 / 189(32.80 \%)$ \\
\hline Non-GCB & $127 / 189(67.20 \%)$ \\
\hline \multicolumn{2}{|l|}{ Response } \\
\hline $\mathrm{CR}, \mathrm{n}(\%)$ & $149 / 189(78.84 \%)$ \\
\hline $\mathrm{PR}, \mathrm{n}(\%)$ & $3 / 189(1.59 \%)$ \\
\hline $\mathrm{SD}$ or $\mathrm{PD}, \mathrm{n}(\%)$ & $37 / 189(19.58 \%)$ \\
\hline ORR (CR+PR), n (\%) & $152 / 189(80.42 \%)$ \\
\hline
\end{tabular}

ECOG PS, Eastern Cooperative Oncology Group performance status; LDH, lactate dehydrogenase; IPI, international prognostic index; GCB, germinal center B cell; CR, complete response; PR, partial response; SD, stable disease; PD, progressive disease; ORR, overall response rate.

p40phox subunit of the NAD(P)H oxidase which regulates Fc $\gamma$ receptor-induced superoxide generation following the internalization of phagosomes [26, 27]. Meanwhile, overproduction of ROS involved in neutrophil death upon exposure to chemotherapy [28], and doxorubicin cardiotoxicity [29], and $\mathrm{NAD}(\mathrm{P}) \mathrm{H}$ oxidase is one of the major sources for superoxide generation [30, 31]. Moreover, activation of NCF4 induces ROS-mediated epithelial-mesenchymal transition (EMT) signaling in HeLa cells [32]. Reconstitution of patient B cells with a NCF4 wild-type could restore exogenous Ag presentation and intracellular ROS generation [33].
NCF4 rs1883112 affects the gene promoter with potential consequences on NCF4 expression and ROS generation [8]. Zhan $\mathrm{S}$ et al. observed the NCF4 that associated with NHL treatment outcome is expressed in hematopoietic cells [34]. Consistent with our findings, Gustafson et al. [20] observed significant association of NCF4 rs1883112 SNP and PFS. Moreover, NCF4 rs1883112 was found as an independent predictor against hematologic, infectious and cardiac toxicity for aggressive B-cell non-Hodgkin lymphoma patients $[8,20]$. Therefore, NCF4 rs1883112 G allele is expected to reduce the tumor cytotoxicity of R-CHOP chemotherapy. 
$A B C G 2$ gene located on chromosome $4 \mathrm{q} 22$, is a ATP-binding cassette transporter, which increase efflux of doxorubicin, vincristine and prednisone from the cell cytoplasm to the extracellular compartment [35]. ABCG2 is one of the major multidrug resistance (MDR) pumps [36], and targeting $A B C G 2$ may have therapeutic value in

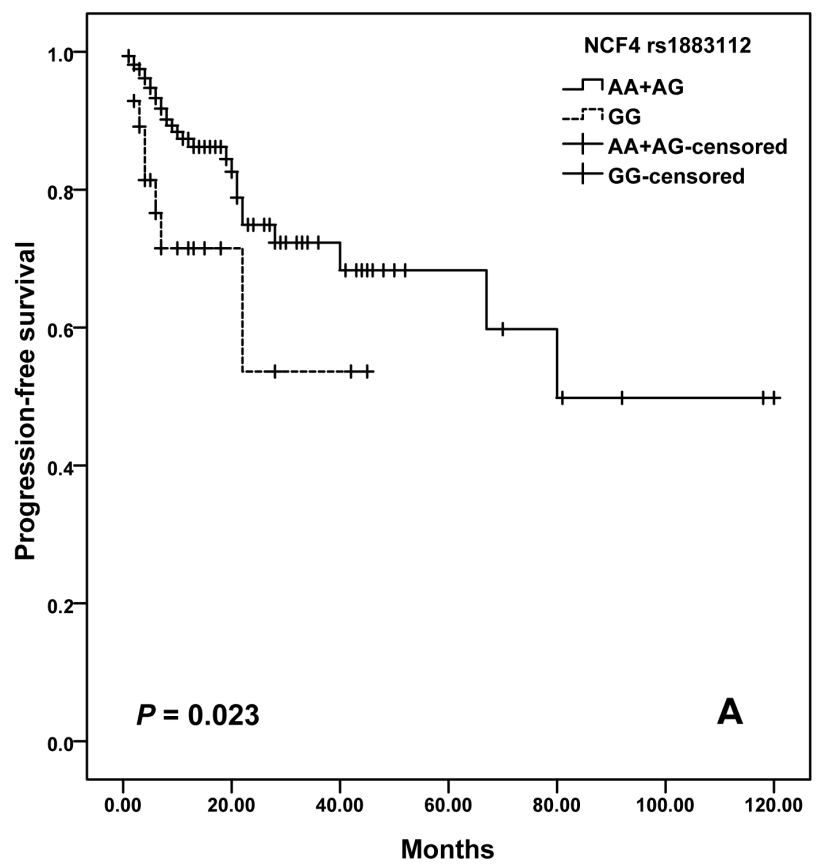

overcoming chemoresistance in DLBCL [37-40]. HeuvelEibrink MM et al. found increased expression of ABCG2 was associated with drug resistance in MCF7 cell lines [41].

The ABCG2 rs2231137 polymorphism results in valine to methionine substitution in the amino acid sequence of the protein. Kondo $\mathrm{C}$ et al. observed no

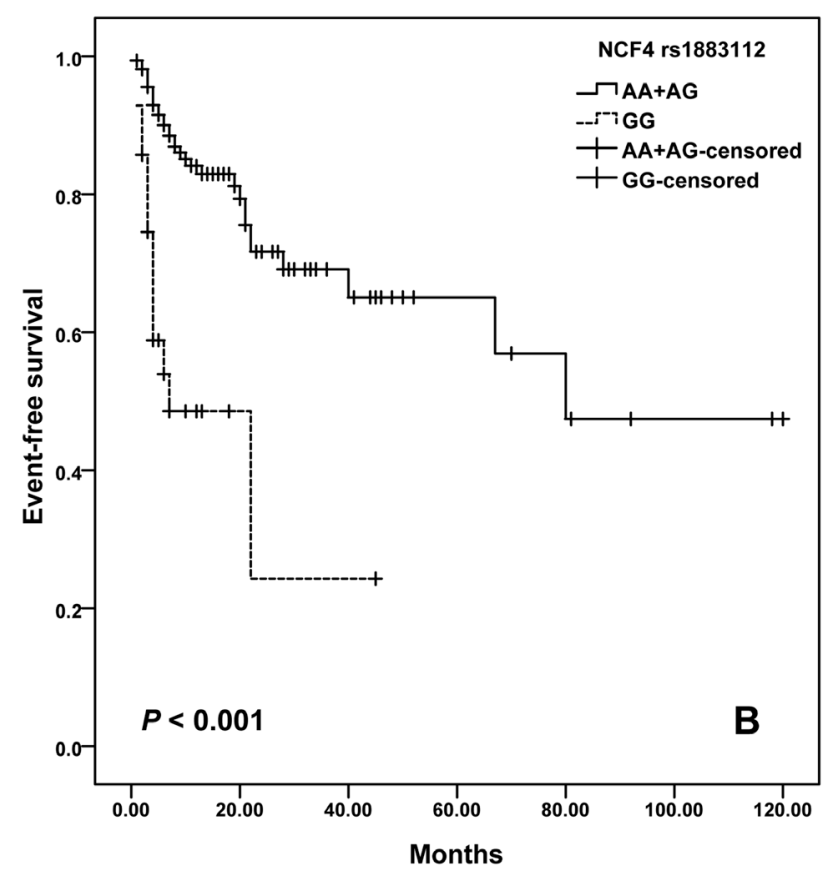

Figure 1: Kaplan-Meier curves illustrate progression-free survival (A) and event-free survival (B) of patients with R-CHOP chemotherapy according to the variant genotypes of NCF4 rs1883112.
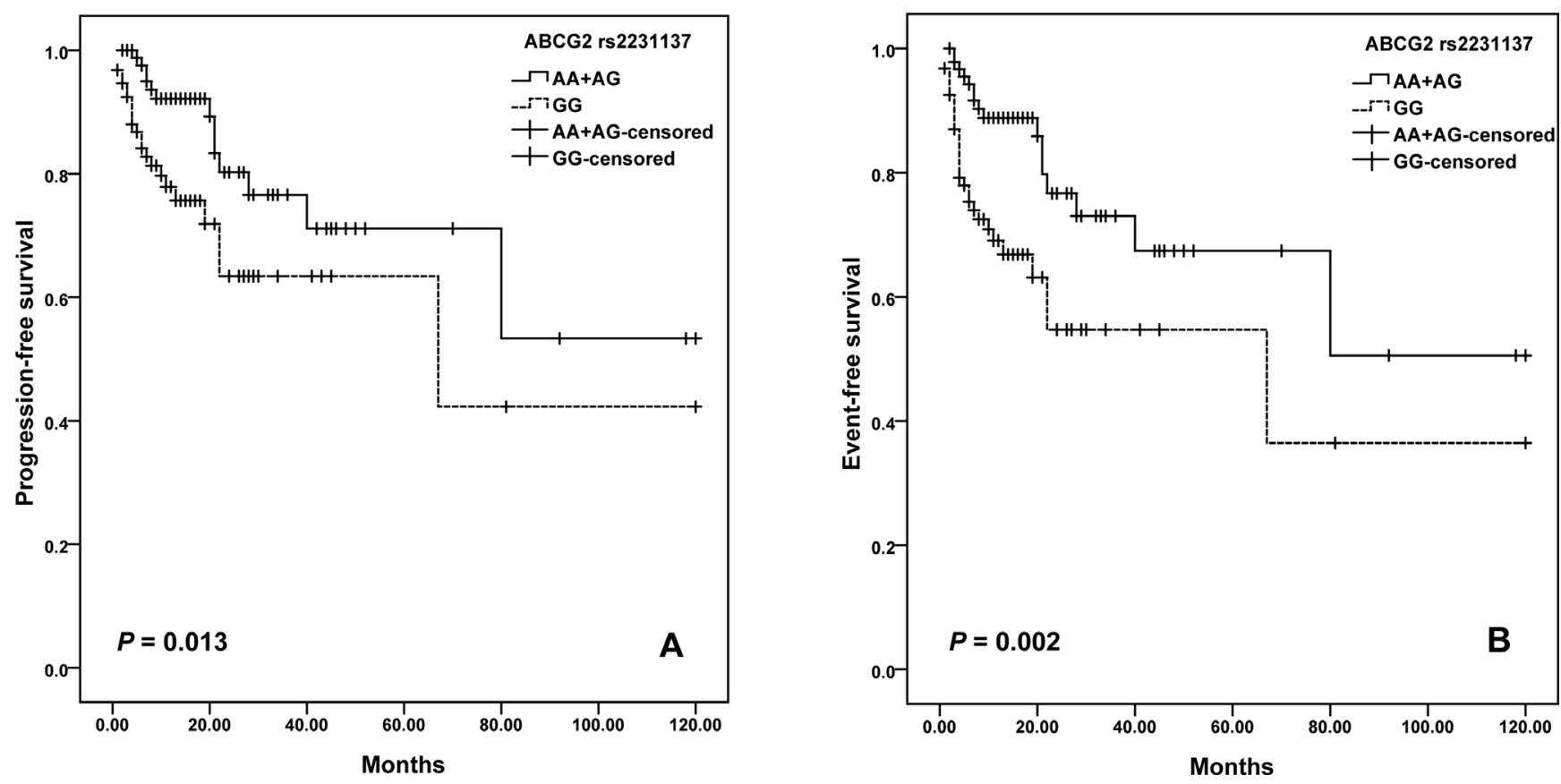

Figure 2: Kaplan-Meier curves illustrate progression-free survival (A) and event-free survival (B) of patients with R-CHOP chemotherapy according to the variant genotypes of $A B C G 2$ rs 2231137 . 
significant difference in the levels of protein expression or transport activity of ABCG2 protein between rs2231137 A and G variant in LLC-KP1 cells [42]. While Poonkuzhali $\mathrm{B}$ et al. found a significantly lower $A B C G 2$ mRNA expression was found in liver tissue of Hispanics with the rs2231137 variant genotype than the individuals with
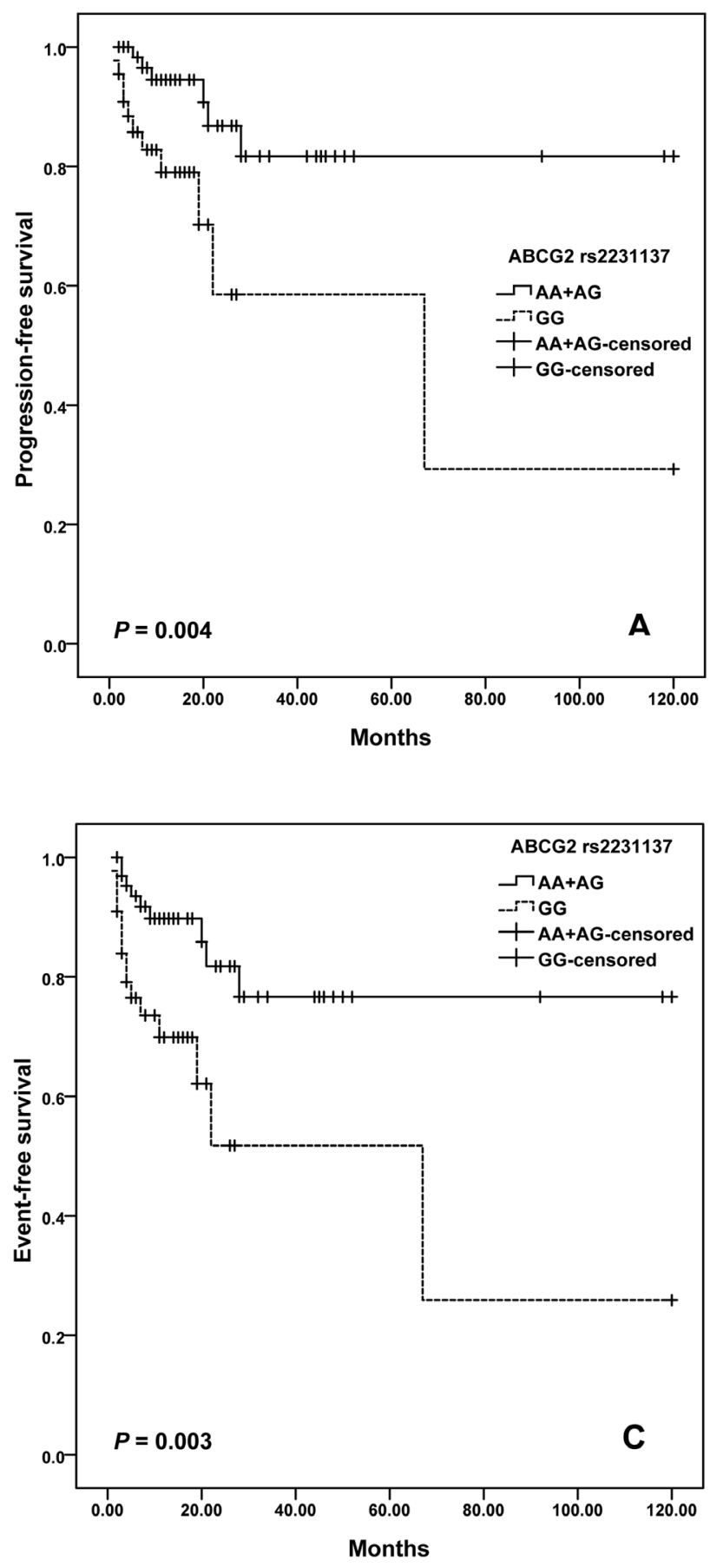

wild genotype. It may be due to alternative splicing of mRNA in rs2231137 variant individuals [43]. One study observed a significantly higher risk of grade 3 or more toxicity was found in the patients with rs2231137 A allele compared to the patients with GG genotype [44]. In another study, rs2231137 AG/AA genotypes were found
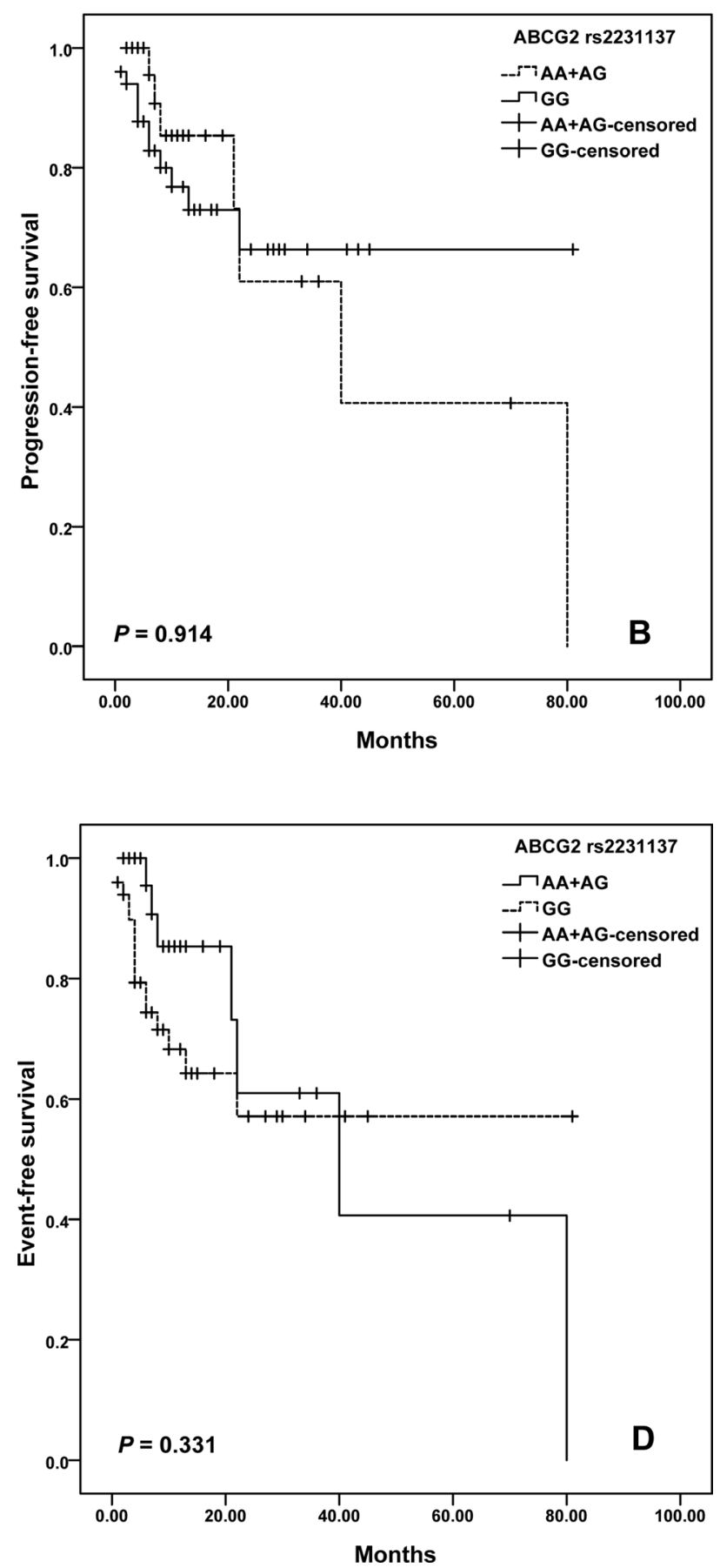

Figure 3: Kaplan-Meier curves illustrate progression-free survival (A) and event-free survival (C) of elder patients (Age $>60$ years), and progression-free survival (B) and event-free survival (D) of younger patients (Age $\leq 60$ years) with R-CHOP according to the variant genotypes of $A B C G 2$ rs 2231137 . 
to be independent factors for protecting against infection [21]. In the current study, we observed that DLBCL patients treated with R-CHOP carrying the rs2231137 GG genotype displayed a poorer PFS and EFS compared to patients who carried the AA or GG genotype. Notably, in this study we found that rituximab clearance and efficacy
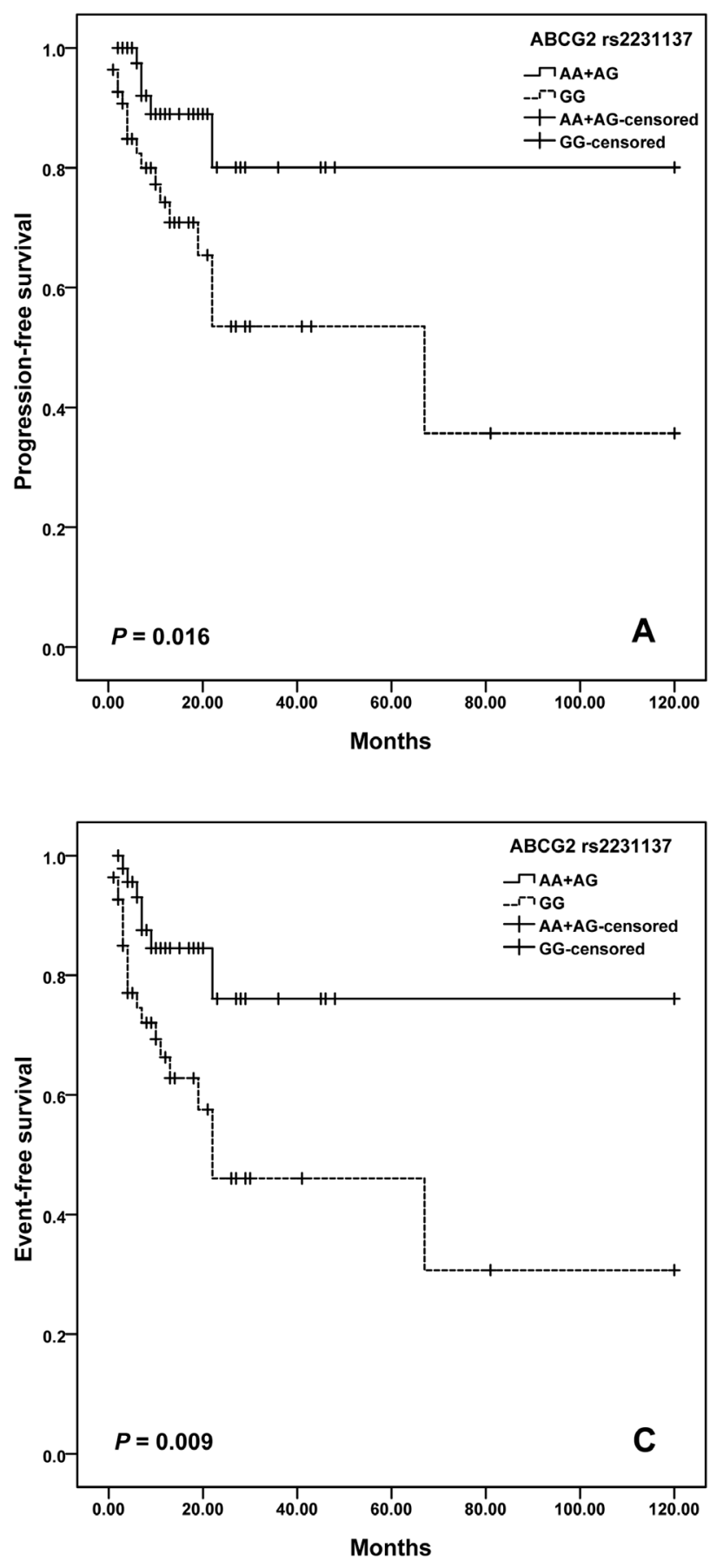

might be gender-biased. Pfreundschuh et al. reported that a better outcome was associated with a slower rituximab clearance and longer exposure times for elderly females but not males [45], while Jaeger et al. suggested that men with a low IPI treated with rituximab had the best outcome [46]. Although no gender or age biased was found for the
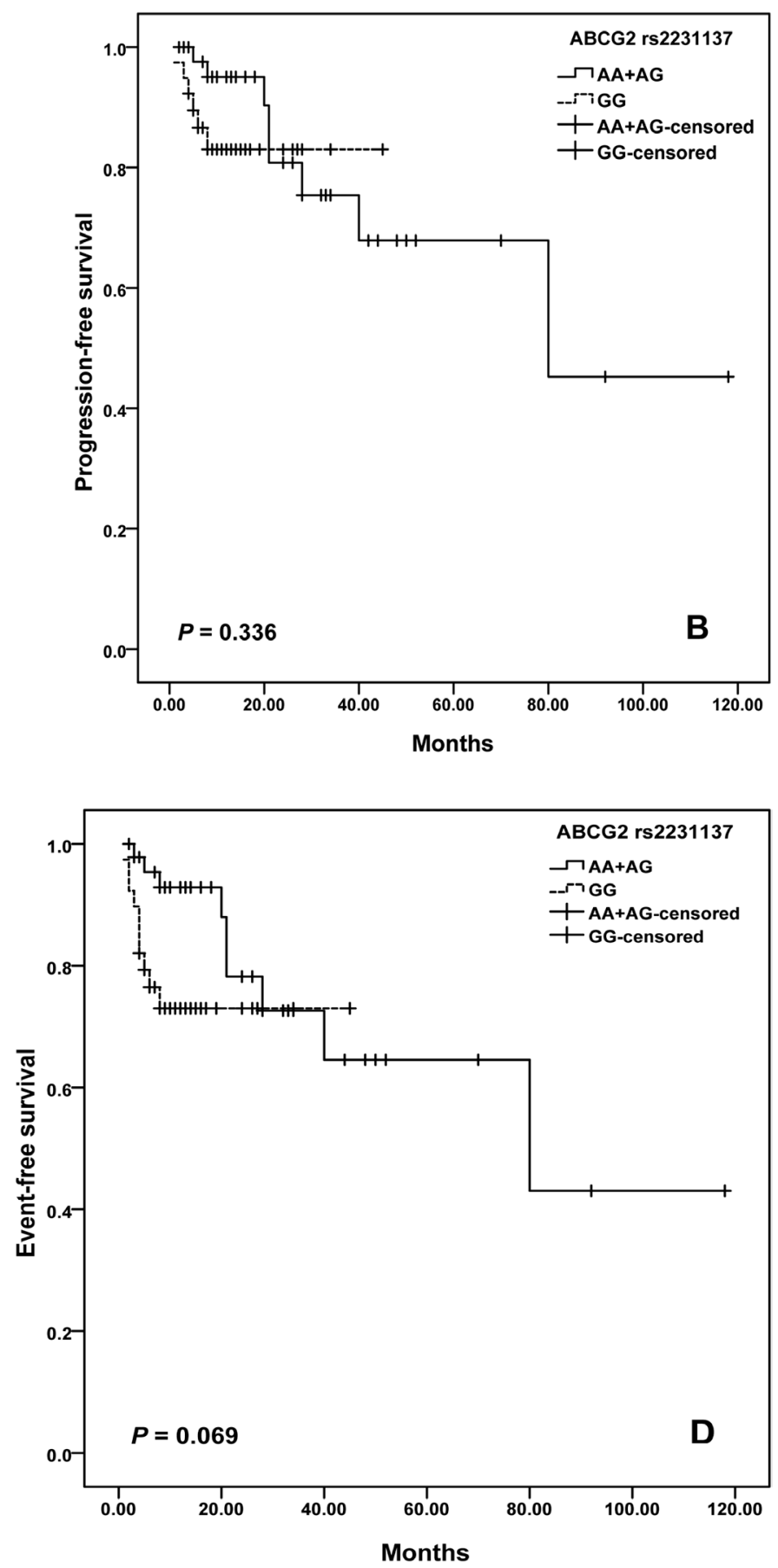

Figure 4: Kaplan-Meier curves illustrate progression-free survival (A) and event-free survival (C) of male patients, and progression-free survival (B) and event-free survival (D) of female patients with R-CHOP according to the variant genotypes of NCF4 rs1883112. 
Table 2: Association between polymorphisms and grade 3-4 hematological toxicity in DLBCL

\begin{tabular}{|c|c|c|c|}
\hline Genotypes & $P^{a}$ & $\mathbf{O R}^{\mathbf{b}}$ & $95 \% \mathrm{CI}$ \\
\hline \multicolumn{4}{|l|}{ rs2070770 } \\
\hline $\mathrm{CC}$ & 0.024 & 0.201 & 0.050-0.807 \\
\hline $\mathrm{CT}$ & 0.087 & 0.238 & $0.046-1.229$ \\
\hline TT & - & - & \\
\hline \multicolumn{4}{|l|}{ rs13058338 } \\
\hline $\mathrm{AA}$ & 0.807 & 1.300 & $0.158-10.677$ \\
\hline AT & 0.034 & 2.659 & $1.074-6.582$ \\
\hline TT & - & - & \\
\hline
\end{tabular}

${ }^{a}$ Comparison of genotype frequencies using Pearson's $\chi^{2}$.

${ }^{\mathrm{b}} \mathrm{OR}$ and $95 \% \mathrm{CI}$ values were calculated by logistic regression.

Table 3: Cox regression analysis of potential factors for PFS and EFS in DLBCL patients adjusting for IPI

\begin{tabular}{|c|c|c|c|c|}
\hline \multirow{2}{*}{ Variable } & & \multicolumn{3}{|c|}{ R-CHOP } \\
\hline & & $P^{a}$ & Hazard ratio & $95 \% \mathrm{CI}$ \\
\hline \multicolumn{5}{|l|}{ PFS survival } \\
\hline \multirow[t]{2}{*}{$C D 20($ rs2070770) } & Dominant mode & 0.193 & 0.584 & $0.259-1.314$ \\
\hline & Recessive mode & 0.251 & 0.311 & $0.042-2.285$ \\
\hline \multirow[t]{2}{*}{ FCGR2A (rs1801274) } & Dominant mode & 0.576 & 0.799 & $0.363-1.756$ \\
\hline & Recessive mode & 0.642 & 1.172 & $0.600-2.290$ \\
\hline \multirow[t]{2}{*}{$A B C G 2$ (rs2231137) } & Dominant mode & 0.641 & 1.290 & $0.442-3.767$ \\
\hline & Recessive mode & 0.054 & 1.987 & 0.989-3.991 \\
\hline \multirow[t]{2}{*}{$A B C G 2(\mathrm{rs} 2231142)$} & Dominant mode & 0.123 & 0.534 & $0.241-1.184$ \\
\hline & Recessive mode & 0.982 & 0.992 & $0.507-1.943$ \\
\hline \multirow[t]{2}{*}{$N A D P H($ rs4673) } & Dominant mode & 0.785 & 1.111 & $0.520-2.376$ \\
\hline & Recessive mode & 0.983 & - & - \\
\hline \multirow[t]{2}{*}{ NCF4 (rs1883112) } & Dominant mode & 0.317 & 1.437 & $0.706-2.927$ \\
\hline & Recessive mode & 0.030 & 2.410 & 1.088-5.338 \\
\hline $\begin{array}{l}\text { RAC2 } \\
\text { (rs13058338) }\end{array}$ & TT vs. AT & 0.556 & 1.247 & $0.598-2.600$ \\
\hline \multirow[t]{2}{*}{ CYP3A5 (rs776746) } & Dominant mode & 0.036 & 0.353 & 0.134-0.935 \\
\hline & Recessive mode & 0.950 & 1.022 & $0.519-2.011$ \\
\hline \multicolumn{5}{|l|}{ EFS survival } \\
\hline$C D 20(\mathrm{rs} 2070770)$ & Dominant mode & 0.715 & 0.884 & $0.455-1.716$ \\
\hline
\end{tabular}

(Continued) 


\begin{tabular}{|c|c|c|c|c|}
\hline \multirow{2}{*}{ Variable } & & \multicolumn{3}{|c|}{ R-CHOP } \\
\hline & & $P^{\text {a }}$ & Hazard ratio & 95\% CI \\
\hline & Recessive mode & 0.361 & 0.515 & $0.124-2.142$ \\
\hline \multirow[t]{2}{*}{ FCGR2A (rs1801274) } & Dominant mode & 0.990 & 0.995 & $0.481-2.061$ \\
\hline & Recessive mode & 0.220 & 1.436 & $0.805-2.560$ \\
\hline \multirow[t]{2}{*}{$A B C G 2(\mathrm{rs} 2231137)$} & Dominant mode & 0.644 & 1.252 & $0.483-3.249$ \\
\hline & Recessive mode & 0.007 & 2.315 & $1.252-4.281$ \\
\hline \multirow[t]{2}{*}{$A B C G 2(\mathrm{rs} 2231142)$} & Dominant mode & 0.041 & 0.479 & $0.236-0.971$ \\
\hline & Recessive mode & 0.710 & 0.894 & $0.495-1.614$ \\
\hline \multirow[t]{2}{*}{$N A D P H(\mathrm{rs} 4673)$} & Dominant mode & 0.771 & 1.103 & $0.570-2.133$ \\
\hline & Recessive mode & 0.978 & - & - \\
\hline \multirow[t]{2}{*}{ NCF4 (rs1883112) } & Dominant mode & 0.390 & 1.310 & $0.707-2.427$ \\
\hline & Recessive mode & 0.001 & 4.464 & 2.339-8.520 \\
\hline$R A C 2(\mathrm{rs} 13058338)$ & TT vs. AT & 0.918 & 1.034 & $0.552-1.937$ \\
\hline \multirow[t]{2}{*}{ CYP3A5 (rs776746) } & Dominant mode & 0.007 & 0.324 & $0.142-0.740$ \\
\hline & Recessive mode & 0.645 & 0.871 & $0.484-1.567$ \\
\hline
\end{tabular}

${ }^{a} P, \mathrm{HR}$ and $95 \% \mathrm{CI}$ were assessed using multivariate Cox regression analysis adjusted for IPI.

Table 4: Genotyping primers of SNPs

\begin{tabular}{|c|c|c|c|}
\hline SNP & Allele & PCR primer & Snapshot primer \\
\hline$C D 20$ rs2070770 & $\mathrm{C} / \mathrm{T}$ & $\begin{array}{l}\text { F: CACTGCTTCCTTTAGGCATTC } \\
\text { R: TACCACACAGTCACACAGATG }\end{array}$ & SR: CCTGGGGGGTCTTCTGATGAT \\
\hline $\begin{array}{l}\text { FCGR2A } \\
\text { rs } 1801274\end{array}$ & $\mathrm{C} / \mathrm{T}$ & $\begin{array}{l}\text { F: GTTTCCTGTGCAGTGGTAATC } \\
\text { R: TGTGTCTTTCAGAATGGCTGG }\end{array}$ & $\begin{array}{l}\text { SR: TTTTTTTGATGGAGAAGGT } \\
\text { GGGATCCAAA }\end{array}$ \\
\hline NCF4 rs 1883112 & $\mathrm{~A} / \mathrm{G}$ & $\begin{array}{l}\text { F: AAATGGAGGCCAGCATTCTAG } \\
\text { R: AGGTTTGCAGGAATCCACTTC }\end{array}$ & SR: AAGGTCACAAGACACCCTGATG \\
\hline$R A C 2$ rs 13058338 & $\mathrm{~A} / \mathrm{G} / \mathrm{T}$ & $\begin{array}{l}\text { F: GAGAGCAGAGACCATGTTTTC } \\
\text { R: ACATCAATCCTTTCTCACCCC }\end{array}$ & $\begin{array}{l}\text { SR: TTTTTTTTTTTTTTTTTTTTTTTTTTT } \\
\text { TTTTTCACCCCCACGGAGGAAGGATGG }\end{array}$ \\
\hline$C Y B A$ rs4673 & $\mathrm{C} / \mathrm{T}$ & $\begin{array}{l}\text { F: TTTGGTGCTTGTGGGTAAACC } \\
\text { R: CCCGAACATAGTAATTCCTGG }\end{array}$ & $\begin{array}{l}\text { SR: TTTTTTTTTTTTTTTTTTTTTTTTT } \\
\text { AGCTTCACCACGGCGGTCATGT }\end{array}$ \\
\hline$A B C C 2$ rs 17222723 & $\mathrm{~A} / \mathrm{T}$ & $\begin{array}{l}\text { F: ATCAGGTTTGCCAGTTATCCG } \\
\text { R: CCAGAGTGAATTTCACACCAC }\end{array}$ & $\begin{array}{l}\text { SR: TTTTTTTTTTTTTTTTTTTTTTTTTT } \\
\text { CGATTTCTGAAACACAATGAGG }\end{array}$ \\
\hline$A B C G 2$ rs 2231142 & $\mathrm{~A} / \mathrm{C}$ & $\begin{array}{l}\text { F: TTGCAGAACTGCAGGTTCATC } \\
\text { R: TAGTTGTTGCAAGCCGAAGAG }\end{array}$ & $\begin{array}{l}\text { SR: TTTTTTTTTTTTTTTCTGAC } \\
\text { GGTGAGAGAAAACTTA }\end{array}$ \\
\hline$A B C G 2$ rs 2231137 & $\mathrm{~A} / \mathrm{G}$ & $\begin{array}{l}\text { F: AAATGAAGCTGCTCATTGCCG } \\
\text { R: TTCAGGTCATTGGAAGCTGTC }\end{array}$ & $\begin{array}{l}\text { SR: TTTTTTTTTTAATGTCGAA } \\
\text { GTTTTTATCCCA }\end{array}$ \\
\hline CYP3A5 rs776746 & $\mathrm{A} / \mathrm{G}$ & $\begin{array}{l}\text { F: GCACTTGATGATTTACCTGCC } \\
\text { R: AGGGTAATGTGGTCCAAACAG }\end{array}$ & $\begin{array}{l}\text { SR: TTTTTTTTTTTTTTTTTTTTTTA } \\
\text { AAGAGCTCTTTTGTCTTTCA }\end{array}$ \\
\hline
\end{tabular}

PCR, polymerase chain reaction; SNP, single nucleotide polymorphism. 
all patients, we found that elder patients ( $>60$ years old) or male patients with GG genotype of rs2231137 had poorer outcomes comparing with A allele. Further studies are needed for the optimization of rituximab dose and schedule in all subgroups of DLBCL patients.

To date, the prognostic value of FCGR2A polymorphism as markers to predict treatment outcome in DLBCL is still being studied [11-13]. Moreover, in rs2070770, the exchange of $\mathrm{T}$ to $\mathrm{C}$ alleles does not alter the encoded amino acid, so this SNP is not able to change the structure or function of the CD20 protein. It is not yet known the potential role of rs2070770 polymorphism in the susceptibility and prognosis of ritumixab therapy. Rs13058338 TA/AA genotypes were reported to be associated with anthracycline-induced cardiotoxicity in the patients with aggressive CD20+ B-cell lymphoma (mainly diffuse large B cell NHL) in Germany and Italy $[8,21,22]$. Despite the small number of chemotherapyinduced cardiotoxicity in patients, we found that DLBCL patients who carried rs13058338 AT genotype showed a low risk of developing grade 3-4 hematological toxicity. The rs 13058338 AT genotype may be a protective factor in DLBCL patients, but further studies are required to confirm the association.

However, the number of patients limited the statistical analysis to demonstrate the relationship between polymorphisms and patient response to chemotherapies. Larger sample sizes and prospective studies, independent collection of clinical outcome and genotyping data, tumor tissue expression analysis, and in vivo functional studies are needed to confirm our results and to clearly characterize the underlying mechanisms.

In conclusion, our study suggests that SNPs involved in the host pharmacogenetics of R-CHOP may have a significant role in predicting the failure of therapy and toxicity in patients with DLBCL in the Chinese population. Our findings will help develop a highly cost effective DLBCL treatment based on these predictive and prognostic biomarker tests.

\section{MATERIALS AND METHODS}

\section{Patient selection}

This cohort of patients had newly diagnosed, histopathologically confirmed, and untreated DLBCL. Some blood samples for the genotyping were not available for the patients who were recruited early in the study and these patients were not included in final analysis. Patients without follow-up and those receiving only palliative treatment were excluded. A detailed questionnaire, including requests for demographics information, was administered to all subjects.

At our institution, patients with DLBCL are typically followed and monitored during and after treatments with regularly scheduled clinical and radiographic examinations. Clinicopathological data were collected from medical records including age, gender, Eastern Cooperative Oncology Group (ECOG) performance status, B symptom, bulky, Extranodal sites, LDH level, bone marrow involvement, IPI scores, Ann Arbor stage, and subtype. The molecular classification of DLBCL was analyzed by immunohistochemistry [24]. During treatment the following variables were evaluated: total number of courses per patient, date and type of response and progression, each course of chemotherapy, red blood cell and platelet transfusion and toxicity. Hematological toxicity (anemia, febrile neutropenia, neutrophil count decreased, platelet count decreased, and white blood cell decreased) and extra-hematological toxicity (diarrhea, gastritis, mucositis oral, nausea, vomiting) were graded according to Common Terminology Criteria for Adverse Events of the National Cancer Institute (CTCAE 4.0).

\section{Treatment protocol}

The R-CHOP 21 protocol was identical to the $\mathrm{CHOP}$ 21 protocol, except for the addition of intravenous infusion of rituximab $\left(375 \mathrm{mg} / \mathrm{m}^{2} / \mathrm{d}\right)$ over 4 to $6 \mathrm{~h}$ at day 1 before the administration of CHOP drugs. Patients in complete remission received a total of six courses chemotherapy, while patients in partial remission completed eight courses of treatment after four courses. According to Ann Arbor criteria, patients with advanced-stage disease received radiotherapy to bulky sites after chemotherapy. Dose reduction and support treatment were prescribed according to R-CHOP 21 guidelines [5, 6]. The response to therapy was evaluated at the end of the fourth course and at the end of treatment. Follow-up visits were scheduled every 3 months for the first 2 years and every 6 months thereafter.

\section{Ethic statement}

The study was approved by the Ethics Committee of Harbin Medical University with the following reference number, HMUIRB20160004. All participants provided written informed consents and all efforts had been made to protect patient privacy and anonymity. The study was conducted according to the Declaration of Helsinki.

\section{DNA extraction and genotyping}

SNPs were selected according to the following criteria: (1) SNPs known to be relevant for the prediction of outcome or toxicity; (2) SNPs affecting regulatory regions and predicting altered expression or function of the gene; (3) SNPs with a minor allele frequency $>5 \%$ in the study population. Nine polymorphisms from 6 genes were analyzed as follows: (1) Antibody-dependent cellular cytotoxicity (CD20 rs2070770, FCGR2A rs1801274); (2) $N A D(P) H$ oxidase subunits $(N C F 4$ rs $1883112, R A C 2$ rs13058338, CYBA rs4673); (3) ATP-binding cassette transporters $(A B C C 2$ rs17222723, ABCG2 rs2231142, 
$A B C G 2$ rs2231137) and (4) Cytochrome P450 enzymes (CYP3A5 rs776746).

DNA samples were extracted from stored blood samples using QIAamp DNA Blood Midi or Maxi kit (Qiagen, Hamburg, Germany). SNP genotyping was carried out using the Multiplex SNaPshot method. Polymerase chain reactions (PCRs) contained 10-50 ng of DNA, $1 \times$ HotStarTaq buffer, $3 \mathrm{mM} \mathrm{MgCl}, 300 \mu \mathrm{M}$ of each dNTP, $0.08 \mu \mathrm{M}$ of each primer, and one unit of HotStar Taq polymerase (Qiagen, Hamburg, Germany) in $20 \mu \mathrm{l}$ reaction volume. The following touchdown PCR program was used: denaturation at $94^{\circ} \mathrm{C}$ for $3 \mathrm{~min}$ followed by 35 cycles of $94^{\circ} \mathrm{C}$ for $15 \mathrm{~s}$, annealing at $55^{\circ} \mathrm{C}$ for $15 \mathrm{~s}$, and extension at $72^{\circ} \mathrm{C}$ for $30 \mathrm{~s}$. This was followed by 30 cycles of denaturation at $96^{\circ} \mathrm{C}$ for 10 $\mathrm{s}$, annealing at $52^{\circ} \mathrm{C}$ for $5 \mathrm{~s}$, and extension at $60^{\circ} \mathrm{C}$ for $30 \mathrm{~s}$ and a final extension at $72^{\circ} \mathrm{C}$ for $3 \mathrm{~min}$. The PCR products were purified by treatment with Exonuclease I (USB Corporation, Cleveland, Ohio, USA) and Shrimp Alkaline Phosphatase (USB Corporation, Cleveland, Ohio, USA) at $37^{\circ} \mathrm{C}$ for 15 min followed by incubation at $80^{\circ} \mathrm{C}$ for $15 \mathrm{~min}$. The extension reaction contained $1 \times$ ABI Prism SNaPshot Multiplex ready reaction mix (Applied Biosystems, Grand Island, NY, USA), $0.5 \mu \mathrm{M}$ of each primer, and $1 \mu \mathrm{l}$ of each PCR product and was carried out as recommended (Applied Biosystems, Grand Island, NY, USA). The extension PCR products were purified using 1 unit of Shrimp Alkaline Phosphatase and then analyzed using an ABI 3730xl Genetic Analyzer. SNP calling was carried out using GENEMAPPERTM software v.4.0 (Applied Biosystems, Grand Island, NY, USA). For quality control, $15 \%$ of the assays were randomly selected for sequencing. The results of the quality control analysis confirmed $100 \%$ concordance.

PRIMER5 (http://frodo.wi.mit.edu/) was used to design primers for each SNP within a multiplex. Extension primers were chosen from the sequence up- or downstream of each SNP immediately, and the primers are listed in Table 4.

\section{Statistical analysis}

Responses were scored according to the International Working Group criteria [25], and assessed by Fisher exact test and Armitage trend test. Progression-free survival (PFS) was defined as time to disease progression, relapse, or death. Event-free survival (EFS) was defined as the time from the beginning of therapy to disease progression, relapse, death, or initiation of additional (off-protocol) or salvage therapy. The endpoints included complete response (CR), partial response (PR), overall response rate (ORR), stable disease (SD), progressive disease (PD), PFS, and EFS. For each SNP, dominant and recessive genetic models were selected for analysis and the model with highest statistical significance was considered to be the best-fitting model. Survival distributions were estimated with the Kaplan-Meier method and compared with the log-rank test. Multivariate analyses were done using Cox proportional-hazard models to estimate hazard ratios and their $95 \%$ confidence interval (CI) for having an event. Analysis for toxicity was performed by Binarylogistic regression analysis with SNP genotypes as the explainable variables.

The statistical analyses were performed using the Statistical Package for Social Sciences (SPSS) version 13.0 statistical software. Statistical significance was set at $P<0.05$ and all tests were two-sided.

\section{ACKNOWLEDGMENTS}

This study was supported by the Program for Changjiang Scholars and Innovative Research Team in University (Grant No. IRT1230); Province in Heilongjiang outstanding youth science fund (Grant No.JC201215); Heilongjiang Province Education Department project (Grant No. 2012CJHB007);

Haiyan fund of Harbin Medical University Cancer Hospital (General Program)(Grant No. JJMS2014-01).

\section{CONFLICTS OF INTEREST}

The authors declare no competing financial interests.

\section{REFERENCES}

1. Jaffe ES. The 2008 WHO classification of lymphomas: implications for clinical practice and translational research. Hematology Am Soc Hematol Educ Program. 2009; 523-531.

2. The International Non-Hodgkin's Lymphoma Prognostic Factors Project. A predictive model for aggressive non-Hodgkin's lymphoma. N Engl J Med. 1993; 329: 9870-9894.

3. McKelvey EM, Gottlieb JA, Wilson HE, Haut A, Talley RW, Stephens R, Lane M, Gamble JF, Jones SE, Grozea PN, Gutterman J, Coltman C, Moon TE. Hydroxyldaunomycin (Adriamycin) combination chemotherapy in malignant lymphoma. Cancer. 1976; 38: 1484-1493.

4. Coiffier B, Lepage E, Briere J, Herbrecht R, Tilly H, Bouabdallah R, Morel P, Van Den Neste E, Salles G, Gaulard P, Reyes F, Lederlin P, Gisselbrecht C. CHOP chemotherapy plus rituximab compared with $\mathrm{CHOP}$ alone in elderly patients with diffuse large-B-cell lymphoma. N Engl J Med. 2002; 346: 235-242.

5. Habermann TM, Weller EA, Morrison VA, Gascoyne RD, Cassileth PA, Cohn JB, Dakhil SR, Woda B, Fisher RI, Peterson BA, Horning SJ. Rituximab-CHOP versus CHOP alone or with maintenance rituximab in older patients with diffuse large B-cell lymphoma. J Clin Oncol. 2006; 24: 3121-3127. 
6. Pfreundschuh M, Trümper L, Osterborg A, Pettengell R, Trneny M, Imrie K, Ma D, Gill D, Walewski J, Zinzani PL, Stahel R, Kvaloy S, Shpilberg O, et al. CHOPlike chemotherapy plus rituximab versus CHOP-like chemotherapy alone in young patients with good-prognosis diffuse large-B-cell lymphoma: a randomised controlled trial by the MabThera International Trial (MInT) Group. Lancet Oncol. 2006; 7: 379-391.

7. Mitroviç Z, Aurer I, Radman I, Ajdukoviç R, Sertiç J, Labar B. FCgammaRIIIA and FCgammaRIIA polymorphisms are not associated with response to rituximab and CHOP in patients with diffuse large B-cell lymphoma. Haematologica. 2007; 92: 998-999.

8. Wojnowski L, Kulle B, Schirmer M, Schlüter G, Schmidt A, Rosenberger A, Vonhof S, Bickeböller H, Toliat MR, Suk EK, Tzvetkov M, Kruger A, Seifert S, et al. NAD(P) $\mathrm{H}$ oxidase and multidrug resistance protein genetic polymorphisms are associated with doxorubicin-induced cardiotoxicity. Circulation. 2005; 112: 3754-3762.

9. Zhang LN, Wang L, Fang C, Zou ZJ, Fan L, Zhang R, Young $\mathrm{KH}, \mathrm{Li} \mathrm{JY}, \mathrm{Xu} \mathrm{W}$. The significance of single nucleotide polymorphism rs2070770 in CD20 gene in Chinese patients with diffuse large B-cell lymphoma. Leuk Lymphoma. 2015; 56: 676-681.

10. Ding H, Jin X, Ding N, Fu Z, Song Y, Zhu J. Single nucleotide polymorphisms of CD20 gene and their relationship with clinical efficacy of R-CHOP in patients with diffuse large B cell lymphoma. Cancer Cell Int. 2013; 13: 58 .

11. Nielsen KR, Steffensen R, Bendtsen MD, RodrigoDomingo M, Baech J, Haunstrup TM, Bergkvist KS, Schmitz A, Boedker JS, Johansen P, Dybkaeær K, Boeøgsted M, Johnsen HE. Inherited inflammatory response genes are associated with B-cell non-Hodgkin's lymphoma risk and survival. PLoS One. 2015; 10: e0139329.

12. Wang SS, Cerhan JR, Hartge P, Davis S, Cozen W, Severson RK, Chatterjee N, Yeager M, Chanock SJ, Rothman N. Common genetic variants in proinflammatory and other immunoregulatory genes and risk for non-Hodgkin lymphoma. Cancer Res. 2006; 66: 9771-9780.

13. Kim DH, Jung HD, Kim JG, Lee JJ, Yang DH, Park YH, Do YR, Shin HJ, Kim MK, Hyun MS, Sohn SK. FCGR3A gene polymorphisms may correlate with response to frontline R-CHOP therapy for diffuse large B-cell lymphoma. Blood. 2006; 108: 2720-2725.

14. Zalba G, San José G, Moreno MU, Fortuño A, Díez J. NADPH oxidase-mediated oxidative stress: genetic studies of the p22(phox) gene in hypertension. Antioxid Redox Signal. 2005; 7: 1327-1336.

15. Kim IS, Kim HG, Kim DC, Eom HS, Kong SY, Shin HJ, Hwang SH, Lee EY, Lee GW. ABCG2 Q141K polymorphism is associated with chemotherapy-induced diarrhea in patients with diffuse large B-cell lymphoma who received frontline rituximab plus cyclophosphamide/ doxorubicin/vincristine/prednisone chemotherapy. Cancer Sci. 2008; 99: 2496-2501.

16. Sauna ZE, Kimchi-Sarfaty C, Ambudkar SV, Gottesman MM. Silent polymorphisms speak: how they affect pharmacogenomics and the treatment of cancer. Cancer Res. 2007; 67: 9609-9612.

17. Cascorbi I. Role of pharmacogenetics of ATP-binding cassette transporters in the pharmacokinetics of drugs. Pharmacol Ther. 2006; 112: 457-473.

18. Mcllwain CC, Townsend DM, Tew KD. Glutathione S-transferase polymorphisms: cancer incidence and therapy. Oncogene. 2006; 25: 1639-1648.

19. Ingelman-Sundberg M, Sim SC, Gomez A, RodriguezAntona C. Influence of cytochrome P450 polymorphisms on drug therapies: pharmacogenetic, pharmacoepigenetic and clinical aspects. Pharmacol Ther. 2007; 116: 496-526.

20. Gustafson HL, Yao S, Goldman BH, Lee K, Spier CM, LeBlanc ML, Rimsza LM, Cerhan JR, Habermann TM, Link BK, Maurer MJ, Slager SL, Persky DO, et al. Genetic polymorphisms in oxidative stress-related genes are associated with outcomes following treatment for aggressive B-cell non-Hodgkin lymphoma. Am J Hematol. 2014; 89: 639-645.

21. Rossi D, Rasi S, Franceschetti S, Capello D, Castelli A, De Paoli L, Ramponi A, Chiappella A, Pogliani EM, Vitolo U, Kwee I, Bertoni F, Conconi A, Gaidano G. Analysis of the host pharmacogenetic background for prediction of outcome and toxicity in diffuse large B-cell lymphoma treated with R-CHOP 21. Leukemia. 2009; 23: 1118-1126.

22. Reichwagen A, Ziepert M, Kreuz M, Gödtel-Armbrust U, Rixecker T, Poeschel V, Reza Toliat M, Nürnberg P, Tzvetkov M, Deng S, Trümper L, Hasenfuss G, Pfreundschuh M, Wojnowski L. Association of NADPH oxidase polymorphisms with anthracycline-induced cardiotoxicity in the RICOVER-60 trial of patients with aggressive CD20 (+) B-cell lymphoma. Pharmacogenomics. 2015; 16: 361-372.

23. Jordheim LP, Ribrag V, Ghesquieres H, Pallardy S, Delarue R, Tilly H, Haioun C, Jardin F, Demangel D, Salles GA, Dumontet C. Single nucleotide polymorphisms in $\mathrm{ABCB} 1$ and $\mathrm{CBR} 1$ can predict toxicity to R-CHOP type regimens in patients with diffuse non-Hodgkin lymphoma. Haematologica. 2015; 100: e204-e206.

24. Hans CP, Weisenburger DD, Greiner TC, Gascoyne RD, Delabie J, Ott G, Müller-Hermelink HK, Campo E, Braziel RM, Jaffe ES, Pan Z, Farinha P, Smith LM, et al. Confirmation of the molecular classification of diffuse large B-cell lymphoma by immunohistochemistry using a tissue microarray. Blood. 2004; 103: 275-282.

25. Cheson BD, Horning SJ, Coiffier B, Shipp MA, Fisher RI, Connors JM, Lister TA, Vose J, Grillo-López A, Hagenbeek A, Cabanillas F, Klippensten D, Hiddemann W, et al. Report of an international workshop to standardize response criteria for non-Hodgkin'slymphomas. NCI Sponsored International Working Group. J Clin Oncol. 1999; 17: 1244. 
26. Lopes LR, Dagher MC, Gutierrez A, Young B, Bouin AP, Fuchs A, Babior BM. Phosphorylated p40PHOX as a negative regulator of NADPH oxidase. Biochemistry. 2004; 43: 3723-3730.

27. Tian W, Li XJ, Stull ND, Ming W, Suh CI, Bissonnette SA, Yaffe MB, Grinstein S, Atkinson SJ, Dinauer MC. Fc gamma R-stimulated activation of the NADPH oxidase: phosphoinositide-binding protein $\mathrm{p} 40$ phox regulates NADPH oxidase activity after enzyme assembly on the phagosome. Blood. 2008; 112: 3867-3877.

28. Scheel-Toellner D, Wang K, Craddock R, Webb PR, McGettrick HM, Assi LK, Parkes N, Clough LE, Gulbins E, Salmon M, Lord JM. Reactive oxygen species limit neutrophil life span by activating death receptor signaling. Blood. 2004; 104: 2557-2564.

29. Minotti G, Menna P, Salvatorelli E, Cairo G, Gianni L. Anthracyclines: molecular advances and pharmacologic developments in antitumor activity and cardiotoxicity. Pharmacol Rev. 2004; 56: 185-229.

30. Ferraro D, Corso S, Fasano E, Panieri E, Santangelo R, Borrello S, Giordano S, Pani G, Galeotti T. Pro-metastatic signaling by c-Met through RAC-1 and reactive oxygen species (ROS). Oncogene. 2006; 25: 3689-3698.

31. Mitsushita J, Lambeth JD, Kamata T. The superoxidegenerating oxidase Nox1 is functionally required for Ras oncogene transformation. Cancer. Res. 2004; 64: 3580-3585.

32. Kim YM, Cho M. Activation of NADPH oxidase subunit NCF4 induces ROS-mediated EMT signaling in HeLa cells. Cell Signal. 2014; 26: 784-796.

33. Crotzer VL, Matute JD, Arias AA, Zhao H, Quilliam LA, Dinauer MC, Blum JS. Cutting edge: NADPH oxidase modulates MHC class II antigen presentation by B cells. J Immunol. 2012; 189: 3800-3804.

34. Zhan S, Vazquez N, Zhan S, Wientjes FB, Budarf ML, Schrock E, Ried T, Green ED, Chanock SJ. Genomic structure, chromosomal localization, start of transcription, and tissue expression of the human p40-phox, a new component of the nicotinamide adenine dinucleotide phosphate-oxidase complex. Blood. 1996; 88: 2714-2721.

35. Cascorbi I. Role of pharmacogenetics of ATP-binding cassette transporters in the pharmacokinetics of drugs. Pharmacol Ther. 2006; 112: 457-473.

36. Dean M, Allikmets R. Complete characterization of the human ABC gene family. J Bioenerg Biomembr. 2001; 33: 475-479.

37. Singh RR, Kunkalla K, Qu C, Schlette E, Neelapu SS, Samaniego F, Vega F. ABCG2 is a direct transcriptional target of hedgehog signaling and involved in stromainduced drug tolerance in diffuse large B-cell lymphoma. Oncogene. 2011; 30: 4874-4886.

38. Kim JE, Singh RR, Cho-Vega JH, Drakos E, Davuluri Y, Khokhar FA, Fayad L, Medeiros LJ, Vega F. Sonic hedgehog signaling proteins and ATP-binding cassette G2 are aberrantly expressed in diffuse large B-cell lymphoma. Mod Pathol. 2009; 22: 1312-1320.

39. Westover D, Li F. New trends for overcoming ABCG2/ BCRP-mediated resistance to cancer therapies. J Exp Clin Cancer Res. 2015; 34: 159.

40. Wen CC, Yee SW, Liang X, Hoffmann TJ, Kvale MN, Banda Y, Jorgenson E, Schaefer C, Risch N, Giacomini KM. Genome-wide association study identifies ABCG2 (BCRP) as an allopurinol transporter and a determinant of drug response. Clin Pharmacol Ther. 2015; 97: 518-525.

41. van den Heuvel-Eibrink MM, Wiemer EA, Prins A, Meijerink JP, Vossebeld PJ, van der Holt B, Pieters R, Sonneveld P. Increased expression of the breast cancer resistance protein (BCRP) in relapsed or refractory acute myeloid leukemia (AML). Leukemia. 2002; 16: 833-839.

42. Kondo C, Suzuki H, Itoda M, Ozawa S, Sawada J, Kobayashi D, Ieiri I, Mine K, Ohtsubo K, Sugiyama Y. Functional analysis of SNPs variants of BCRP/ABCG2. Pharmcol Res. 2004; 21: 1895-1903.

43. Poonkuzhali B, Lamba J, Strom S, Sparreboom A, Thummel K, Watkins P, Schuetz E. Association of breast cancer resistance protein/ABCG2 phenotypes and novel promoter and intron 1 single nucleotide polymorphisms. Drug Metab Dispos. 2008; 36: 780-795.

44. Hampras SS, Sucheston L, Weiss J, Baer MR, Zirpoli G, Singh PK, Wetzler M, Chennamaneni R, Blanco JG, Ford L, Moysich KB. Genetic polymorphisms of ATP-binding cassette $(\mathrm{ABC})$ proteins, overall survival and drug toxicity in patients with Acute Myeloid Leukemia. Int J Mol Epidemiol Genet. 2010; 1: 201-207.

45. Pfreundschuh M, Müller C, Zeynalova S, Kuhnt E, Wiesen MH, Held G, Rixecker T, Poeschel V, Zwick C, Reiser M, Schmitz N, Murawski N. Suboptimal dosing of rituximab in male and female patients with DLBCL. Blood. 2014; 123: 640-646.

46. Jaeger U, Trneny M, Melzer H, Praxmarer M, Nawarawong W, Ben Yehuda D, Goldstein D, Mihaljevic B, Ilhan O, Ballova V, Hedenus M, Hsiao LT, Au WY, et al. Rituximab maintenance for patients with aggressive B-cell lymphoma in first remission: results of the randomized NHL13 trial. Haematologica. 2015; 100: 955-963. 